\title{
BIOSYNTHESIS OF VITAMIN K AND OTHER NATURAL NAPHTHOQUINONES
}

\author{
RONALD BENTLEY \\ Department of Biochemistry, Faculty of Arts and Sciences, \\ University of Pittsburgh, Pittsburgh, Pennsylvania 15261, USA
}

\begin{abstract}
Compounds with vitamin $\mathrm{K}$ activity, menaquinone and phylloquinone, are biosynthesized from shikimic acid (or a close relative) and either 2-ketoglutaric acid or glutamic acid. The mechanism of the condensation and the nature of possible intermediates are discussed. Flaviolin (produced by Aspergillus niger) and 2,7-dimethoxynaphthazarin (produced by Streptomycete 12396) are shown to be typical acetate polymalonate compounds. Other routes to naturally occurring naphthoquinones are briefly reviewed.
\end{abstract}

\section{INTRODUCTION}

Nature has been truly prolific with the naturally occurring quinones and quinols, not only with respect to their numbers, but also with respect to the many diverse pathways for their biosynthesis. In 1971 Thomson estimated there were more than $\mathbf{3 8 0}$ members of the three main structural classesanthraquinones, naphthoquinones and benzoquinones ${ }^{1}$. With the steady rate at which new compounds have been discovered, the number of natural quinones must now approach 500 . As to biosynthetic pathways to quinones, there are at least five each to benzoquinones and naphthoquinones, and two to anthraquinones ${ }^{2}$.

Many of the naturally occurring quinones are typical 'secondary' metabolites for which no obvious metabolic role exists. Others, particularly in the benzo- and naphthoquinone classes, are 'primary' metabolites having important and well-studied biological roles. We have been investigating the biosynthesis of metabolites of both kinds with increasing concentration on naphthoquinones. The primary metabolites of interest to us are menaquinones (vitamins $\mathrm{K}_{2}$ ); the secondary metabolites are simple hydroxylated naphthoquinones produced by various micro-organisms (flaviolin, mompain and 2,7-dimethoxynaphthazarin). To give a complete picture of the biosynthetic pathways to naphthoquinones, the work of many other groups will be cited.

\section{THE ROLE OF SHIKIMIC ACID}

Shikimic acid is one of the few compounds to have undergone the change from obscure secondary metabolite to fundamental primary metabolite. In addition to its role in providing protein components (phenylalanine, 


\section{RONALD BENTLEY}

tyrosine and tryptophan), it is frequently used as the bridge between the linear carbon chains of carbohydrates and aromatic compounds. Nowhere is this more important than with the naphthoquinones. From shikimate are formed three benzoate derivatives ( $o$-succinylbenzoate, 4-hydroxybenzoate and homogentisate) which in turn serve as precursors to naphthoquinones.

\section{A. Naphthoquinones derived from o-succinylbenzoate-general}

Certain plant naphthoquinones, and the plant and bacterial vitamins $\mathrm{K}$, are derived by the pathway:

$$
\text { shikimate } \rightarrow o \text {-succinylbenzoate } \rightarrow \text { naphthoquinone }
$$

It will be convenient to consider all of these materials in the same section. The structure and nomenclature of the materials with vitamin $\mathrm{K}$ activity is as follows:<smiles>[R]C[C@@](C)(CC(C)=CCC1=C(C)C(=O)c2ccccc2C1=O)CC(C)(C)CCC(C)C</smiles><smiles>[R]C1=C(CC)C(=O)c2ccccc2C1=O</smiles><smiles>[H][Z]([H])([14CH3])CC(C)=CCC(C)(C)CCCCC(C)=CCC1=C(C)C(=O)c2ccccc2C1=O</smiles>

1, Phylloquinone (formerly vitamin $\mathrm{K}_{1}$ ); abbreviation, $\mathrm{K}$

2, $\mathrm{R}=\mathrm{CH}_{3}$, Menaquinone-n (formerly vitamin $\mathrm{K}_{2}(5 \mathrm{n})$ ); abbreviation, $\mathrm{MK}-\mathrm{n}$.

$\mathbf{R}=\mathbf{H}$, Desmethylmenaquinone; abbreviation, DMK-n

3, 5',6'-Dihydromenaquinone-n; abbreviation MK-9 (II- $\mathrm{H}_{2}$ )- the Roman numeral refers to the second isoprene residue out from the nucleus

Cox and Gibson were the first to propose a role for shikimate in menaquinone biosynthesis ${ }^{3}$. They administered $\left[\mathrm{U}-{ }^{14} \mathrm{C}\right]$ shikimate to Escherichia coli, and separated ubiquinone and MK-8 by thin layer chromatography. The MK-8 spot was radioactive; since 3,4-dihydroxybenzaldehyde inhibited the conversion, an intermediate role was assigned to this compound. A partial degradation of the radioactive MK- 8 suggested that the benzenoid ring A originated in shikimate but failed to show how many carbon atoms 


\section{BIOSYNTHESIS OF VITAMIN $\mathrm{K}$}

were utilized ${ }^{4}$. Similarly, Whistance, Threlfall and Goodwin reported a conversion of $\left[\mathrm{U}^{14}{ }^{14} \mathrm{C}\right]$ shikimate to phylloquinone in etiolated maize shoots in $1966^{5}$.<smiles>[R]C(=O)Oc1c(CC=C([R])C)c(C)c(OC(C)=O)c2ccccc12</smiles><smiles>COc1c(C)c(CC=O)c(OC(C)=O)c2ccccc12</smiles><smiles>COc1c(CC(=O)O)c([125I])c(OC(=O)O)c2ccccc12</smiles>

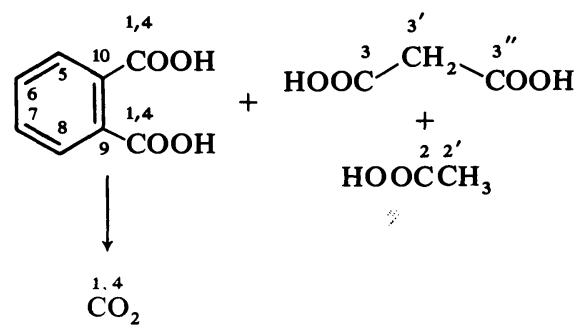

In continuation of our own interests in the biosynthesis of isoprenoid and other quinones, we devised rigorous methods for purification and chemical degradation of menaquinone samples. Single spots of a menaquinone isolated from thin layer chromatograms were examined by mass spectrometry; such 'pure' samples contained substantial amounts of fatty acid esters, other isoprenoid and unidentified compounds. Clearly, scanning of thin layer chromatograms to detect radioactivity was fraught with danger. 
Purification by gel filtration on Sephadex LH-20 (or LH-50) was found to be possible on a milligram scale using the earlier micro procedures of Nyström and Sjövall ${ }^{6}$. An organic solvent system was used (iso-octane:methanol: chloroform, $2: 1: 1$ ); not only were menaquinone samples obtained showing a clean mass spectrum, but also such columns could be used to resolve isoprenylogs-e.g., MK-8(II- $\left.\mathrm{H}_{2}\right)$ from MK-9 (II- $\left.\mathrm{H}_{2}\right)^{7,8}$.

Although ozonolysis of the quinol diacetate (4) appeared an attractive degradative possibility, and was actually used in the early structure determinations, attempts to use this reaction on a small scale $(50-100 \mathrm{mg}$ ) were very unpromising. An alternative was found in hydroxylation of the side chains $\left(\mathrm{OsO}_{4}\right)$ followed by periodate cleavage of the glycols; aldehydes were then oxidized to their acids with permanganate. The key product obtained from these manipulations was the naphthylacetic acid (5), which was further degraded with alkaline peroxide. Ring $A$ and the associated quinone carbon atoms were thus obtained as phthalic acid; decarboxylation of phthalate gave carbon dioxide derived from carbons 1 and 4.

With suitable purification and degradation techniques in hand, a detailed study of menaquinone biosynthesis was undertaken ${ }^{9,10}$. [U- $\left.{ }^{14} \mathrm{C}\right]$ shikimate was a very effective precursor to MK-8, particularly in $E$. coli. In the best case, $I=1.6$ per cent, $D=5.3$. (Throughout this paper, the percentage incorporation value, $I$, is:

$$
\frac{\text { total d.p.m. in recovered metabolite }}{\text { total d.p.m. in added precursor }} \times 100
$$

The dilution value, $D$, is:

$$
\text { specific activity of recovered metabolite })
$$

Likewise, $\left[\mathrm{U}-{ }^{14} \mathrm{C}\right]$ shikimate was incorporated into the menaquinones of Mycobacterium phlei and Streptomyces albus, although less effectively. Thus, for MK-9 $\left(\mathrm{II}-\mathrm{H}_{2}\right)$ in $M$. phlei, $I=0.02$ per cent, $D=3300$; and for the complex menaquinone mixture of $S$. albus, $I=0.007$ per cent, $D=16000$.

Using the reactions just described, labelled menaquinone samples biosynthesized from $\left[\mathrm{U}-{ }^{14} \mathrm{C}\right]$ shikimate (6) were degraded, with the results shown in Table 1. The material from E. coli contained $89 \%$ of the total radioactivity in ring $\mathrm{A}+\mathrm{C}-1+\mathrm{C}-4$. The distribution of activity between ring $A$ and these two quinonoid carbons $(\mathrm{C}-1+\mathrm{C}-4)$ was $5.5: 1$-in excellent agreement with the average value found for the ratio of ring carbons to carboxyl carbon atoms in the samples of $\left[\mathrm{U}-{ }^{14} \mathrm{C}\right]$ shikimate $(5.9: 1,4.4: 1$, 6.6:1 and 4.7:1 -average $=5.4: 1$ ). Although with the two other organisms shown in Table 1 there was more randomization of ${ }^{14} \mathrm{C}$ into the prenyl side chain, the ratio ring A activity: carboxyl activity was of the same order5.1:1 for S. albus and 4.6:1 for M. phlei. Hence, we concluded that the intact carbon skeleton of shikimate is used in menaquinone biosynthesis in these bacteria. A similar conclusion was reached by Leistner, Schmitt and Zenk, using Bacillus megaterium; the labelled menaquinone was in their work degraded to phthalic acid by refluxing with $\mathrm{KMnO}_{4}{ }^{11}$. 
Table 1. Distribution of ${ }^{14} \mathrm{C}$ in menaquinone samples biosynthesized from $\left[\mathrm{U}-{ }^{14} \mathrm{C}\right]$ shikimate

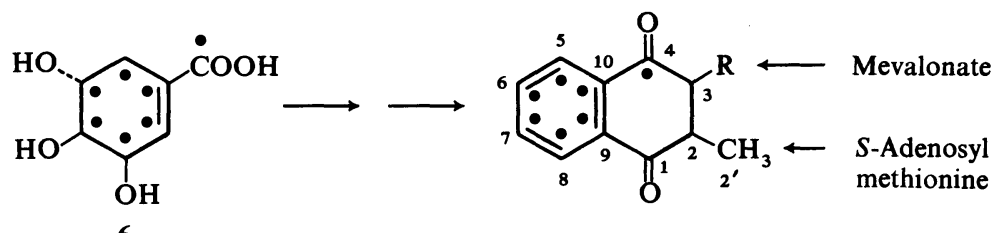

6

\begin{tabular}{lccc}
\hline \multirow{2}{*}{ MK carbon atoms } & \multicolumn{3}{c}{$\%$ of total activity in quinol diacetate } \\
& E. coli & M. phlei & S. albus \\
\hline C-5 to C-10 & 75 & 55 & 66 \\
C-1 + C-4 & 14 & 12 & 16 \\
C-3 + C-3' + C-3" & 0 & 3 & 9 \\
C-2 + C-2' & 2 & 1 & 0 \\
\hline
\end{tabular}

Since the methyl substituent originates from methionine and the isoprenoid side chain from mevalonate ${ }^{12}$, the origins of the menaquinone carbon atoms were known with the exception of three carbon atoms in ring $B$. Identification of the precursor for the 'missing' three-carbon unit was unexpectedly difficult. Compounds such as pyruvate, glycerol, acetate and malonate were not well utilized for menaquinone biosynthesis, but slightly better $I$ values (and low $D$ values) were obtained with alanine and serine ${ }^{13}$.

Our results with these three-carbon amino acids suggested a more detailed examination. To simplify the problem somewhat, Campbell worked on lawsone (9, 2-hydroxy-1,4-naphthoquinone) produced by Impatiens balsamina, since it had already been shown that shikimate was incorporated into this metabolite ${ }^{14}$. Furthermore, degradation of lawsone from $\left[\mathrm{U}-{ }^{14} \mathrm{C}\right]$ shikimate was possible by oxidation to phthalic acid and decarboxylation of the latter. Since 15.8 per cent of total lawsone activity was present in the $\mathrm{CO}_{2}$, it was apparent that the utilization of shikimate was analogous for both the simple plant naphthoquinone and the isoprenoid bacterial naphthoquinone.

Although Campbell found [ $\left.\mathrm{U}-{ }^{14} \mathrm{C}\right]$ alanine to be well utilized in I. balsamina, the activity ratio $(\mathrm{C}-2+\mathrm{C}-3) /(\mathrm{C}-1+\mathrm{C}-4)$ was $73: 13$ rather than the expected $2: 1$ for utilization of a three-carbon fragment ${ }^{15}$. With $\left[\mathrm{U}-{ }^{14} \mathrm{C}\right]-$ aspartate the same ratio was 35:46; hence, it appeared that neither of these acids functioned directly as a precursor. In attempting to rationalize a number of observations, Campbell considered that succinic semialdehyde, probably as its thiamin pyrophosphate (TPP) complex (7), might be the immediate source of the $\mathrm{C}_{3}$ unit. To test this hypothesis, $\left[2-{ }^{14} \mathrm{C}\right]$ glutamate was fed to I. balsamina as a source of $\left[2-{ }^{14} \mathrm{C}\right] 2$-ketoglutarate $(8)$ and hence the postulated complex. This compound was indeed well incorporated into lawsone $(I=1.4$ per cent based on $\mathrm{L}$ enantiomer); moreover, degradation to phthalate with alkaline peroxide showed 99 per cent of the activity to be associated with the quinone positions.

Hence, for the first time, a realistic possibility for biosynthesis of lawsone, menaquinone, etc., was apparent. The 'missing' three-carbon unit was actually 


\section{RONALD BENTLEY}

a five-carbon dicarboxylic acid-either glutamate or 2-ketoglutaratewhich lost the carboxyl groups at both ends of the molecule. A likely mechanism was an initial Michael-type addition of the succinic semialdehyde-TPP complex (7) to the double bond of shikimate ('a') and Claisen condensation ('b') to form the second ring.

These observations were next extended to the bacterial menaquinones ${ }^{10,16}$. With labelled glutamates $\left(\mathrm{U}-{ }^{14} \mathrm{C}\right.$ and $\left.2-{ }^{14} \mathrm{C}\right), I$ values for conversion to menaquinones varied from 0.02 to 0.002 per cent, $D$ values from 8 to 35000 ; bacteria used were M. phlei, E. coli, Corynebacterium diphtheriae and S. albus.

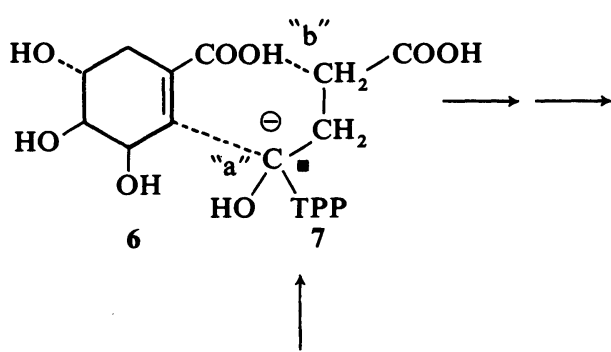<smiles>[R]OC1CC(=O)c2ccccc2C1=O</smiles><smiles>O=C1C=C(O)C(=O)c2ccccc21</smiles>

9<smiles>O=C(O)c1ccccc1C(=O)O</smiles>

Using the previously described degradation, the results shown in Table 2 were obtained. Clearly, $\left[\mathrm{U}-{ }^{14} \mathrm{C}\right]$ glutamate contributes essentially equal amounts of radioactivity to $\mathrm{C}-2, \mathrm{C}-3$ and $\mathrm{C}-4(\mathrm{C}-1)$, while $\left[2-{ }^{14} \mathrm{C}\right]$ glutamate labels only C-4(C-1) and not C-2 and C-3. Similarly, $\left[\mathrm{U}-{ }^{14} \mathrm{C}\right] 2$-ketoglutarate

Table 2. Incorporation of glutamate and 2-ketoglutarate into bacterial menaquinones<smiles>N[C@H](CCC(=O)O)C(=O)O</smiles>

$\left[\mathrm{U}-{ }^{14} \mathrm{C}\right]$ Glutamate<smiles>O=C(O)CCCC(=O)C(=O)O</smiles>

$\left[2-{ }^{14} \mathrm{C}\right]$ Glutamate<smiles>[R]CC(C)=CCC1=C(C)C(=O)c2ccccc2C1=O</smiles>

$\left[\mathrm{U}-{ }^{14} \mathrm{C}\right] 2-$ Ketoglutarate

\begin{tabular}{|c|c|c|c|c|c|c|}
\hline \multirow{2}{*}{$\begin{array}{l}\text { MK carbon } \\
\text { atoms }\end{array}$} & \multirow[b]{2}{*}{ E. coli } & \multirow[b]{2}{*}{ M. phlei } & \multicolumn{2}{|c|}{$\begin{array}{l}\% \text { of MK dihydro } \\
\text { diacetate activity }\end{array}$} & \multirow[b]{2}{*}{ C. diphtheriae } & \multirow[b]{2}{*}{ E. col } \\
\hline & & & C. diphtheriae & E. coli & & \\
\hline C-5 to C-10 & 0 & 11 & 1 & 5 & 4 & 5 \\
\hline C-4 (or C-1) & 18 & 4 & 24 & 25 & 37 & 16 \\
\hline $\mathrm{C}-2$ & 14 & 5 & 20 & 0 & 0 & 15 \\
\hline C-3 & 14 & 3 & 16 & 0 & 0 & 17 \\
\hline
\end{tabular}


labels C-2, C-3 and C-4(C-1) equally when administered to $E$. coli $(I=$ 0.011 per cent $)^{17}$. In lawsone biosynthesis, utilization of $\left[\mathrm{U}-{ }^{14} \mathrm{C}\right] 2$-ketoglutarate also takes place $\left(I=0.2 \text { per cent, } D=1.8 \times 10^{4}\right)^{18}$. While the activity at C-3 and C-4 was equal (40 per cent of total activity), that at C-2 was only 19.4 per cent of the total activity. The lower specific activity at $\mathrm{C}-2$ was attributed to admixture of the $\left[\mathrm{U}-{ }^{14} \mathrm{C}\right] 2$-ketoglutarate with $[1,2,3-$ ${ }^{14} \mathrm{C}_{3}$ ]2-ketoglutarate generated through the tricarboxylic acid cycle.

While there must be several intermediates following the initial reaction, only one has been well established and tentative evidence has been accumulated for a second. In 1970 Dansette and Azerad found that $\left[{ }^{14} \mathrm{C}\right] o$-succinylbenzoate (10, labelled in the benzoate carboxyl and carbonyl groups) was efficiently incorporated into bacterial menaquinones in $M$. phlei $(I=$ 70 per cent), in $E$. coli $(I=2.3$ per cent), in Aerobacter aerogenes $(I=0.2$ per cent) and in plant naphthoquinones (for lawsone biosynthesis, $I=20$ per cent; for juglone biosynthesis in Juglans regia, $I=6$ per cent) ${ }^{19}$. On degradation with $\mathrm{KMnO}_{4}$, all of the radioactivity of $\mathrm{MK}-9$ (II- $\mathrm{H}_{2}$ ) (from M. phlei) was recovered in phthalate; decarboxylation of the phthalate showed that label was present exclusively in C-1 and C-4 of the ring. Similar results were obtained for lawsone and juglone.

We have confirmed the utilization of succinylbenzoate in $E$. coli, using material labelled in the side chain methylene groups $\left(\left[2,3-{ }^{14} \mathrm{C}_{2}\right] 4(2\right.$ '-carboxyphenyl)-4-oxobutyrate, $I=1.8$ per cent, $D=6.3$ ). On the other hand, no radioactivity was incorporated into menaquinone from material labelled in the carboxyl group of the succinyl unit (i.e. $\left[1-{ }^{14} \mathrm{C}\right] 4-\left(2^{\prime}\right.$-carboxyphenyl)4-oxobutyrate). Hence, as expected, decarboxylation must take place at some stage.
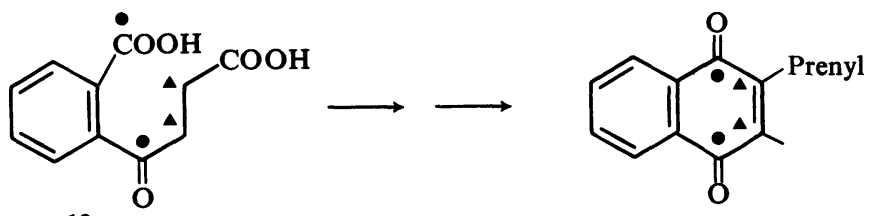

10

Evidence that $o$-succinylbenzoate is actually present in tissue, and is an obligatory intermediate in lawsone biosynthesis, has now been obtained for I. balsamina ${ }^{20}$. After feeding $\left[\mathrm{U}-{ }^{14} \mathrm{C}\right]$ glutamate to this plant, acidic materials were recovered and esterified, then chromatographed on Sephadex LH-20 using isooctane:chloroform:methanol, 2:1:1. Fractions from this column were examined by gas chromatography and proportional counting. A radioactive peak with the retention time and mass spectrum of methyl 4-(2'-carboxymethoxyphenyl)-4-oxobutyrate was obtained. Additional evidence was conversion to the semicarbazone after carrier addition and crystallization of the derivative to constant specific activity.

As far as other intermediates are concerned, Campbell ${ }^{15}$ suggested formation of the second ring by a Claisen-type condensation and Robins, Campbell and Bentley later considered that a role for 1,4-dihydroxy-2naphthoic acid (11) was likely ${ }^{16}$. There is, however, little direct evidence to validate this possibility. 
<smiles>O=C(O)CCC(=O)c1ccccc1C(=O)O</smiles>

10<smiles>CO[N+](C)(C)C(C)C</smiles>

In a study of compounds which will replace the normal vitamin $\mathbf{K}$ requirement of the anaerobe Bacteroides melaninogenicus, we have distinguished five groups of compounds--the classification being made on the relationship between concentration and growth-promoting ability ${ }^{21}$. The dihydroxynaphthoate (11) is in 'Group 1' and is equally effective with phylloquinone and menaquinone at $10^{-5} \mathrm{M}$. In another group (Group 4) are found shikimate, chorismate and succinylbenzoate. These materials are good growth promoters but require higher concentrations $-\geqslant 10^{-3} \mathrm{M}$ (see Table 3). This evidence for a role for dihydroxynaphthoate can only be regarded as tentative, since another compound, 1,4-naphthoquinone itself, also fell in the Group 1 classification-and other evidence eliminates 1,4-naphthoquinone as an intermediate in organisms such as $E$. coli and $M$. phlei.

Table 3. Growth-promoting capabilities of possible intermediates for B. melaninogenicus

\begin{tabular}{|c|c|c|}
\hline Group & Characteristics & Compounds \\
\hline 1 & $\begin{array}{l}\text { Highly effective as growth promoters } \\
\text { at } 10^{-5} \mathrm{M} \text {, but inhibitors at } \geqslant 10^{-3} \mathrm{M}\end{array}$ & $\begin{array}{l}\text { K, MK-9 (no inhibition at high } \\
\text { concentrations); 2-methyl-1,4-naphtho- } \\
\text { quinone; 1,4-naphthoquinone; } \\
\text { 1,4-dihydroxy-2-naphthoic acid }\end{array}$ \\
\hline 2 & $\begin{array}{l}\text { Effective as growth promoters at } 10^{-5} \\
\text { to } 10^{-4} \mathrm{M} \text {, but inhibitors at } \geqslant 10^{-3} \mathrm{M}\end{array}$ & $\begin{array}{l}\text { Lawsone; 1-hydroxy-2-naphthoic acid; } \\
\text { 6-methyl-1,4-naphthoquinone; } \\
\text { DL- } \alpha \text {-tocopherol and its quinone }\end{array}$ \\
\hline 3 & $\begin{array}{l}\text { Weakly effective as a growth promoter } \\
\text { at } 10^{-5} \mathrm{M} \text {, but inhibitor at } \geqslant 10^{-3} \mathrm{M}\end{array}$ & 1-Naphthol \\
\hline 4 & $\begin{array}{l}\text { Highly effective as growth promoters } \\
\text { but only at high concentrations of } \\
\geqslant 10^{-3} \mathrm{M}\end{array}$ & $\begin{array}{l}\text { Shikimic acid; chorismic acid; } \\
o \text {-succinylbenzoic acid }\end{array}$ \\
\hline 5 & $\begin{array}{l}\text { No growth over the entire range } 10^{-2} \\
\text { to } 10^{-8} \mathrm{M}\end{array}$ & $\begin{array}{l}\text { Benzoic acid; phthalic acid; flaviolin; } \\
\text { ubiquinone-8 }\end{array}$ \\
\hline
\end{tabular}

More recently, we have synthesized $\left[2,3-{ }^{14} C_{2}\right] 1,4$-dihydroxy-2-naphthoate and have administered it to $E$. coli. In contrast to our usual experimental conditions, anaerobic growth conditions were employed since this compound is easily oxidized. An excellent incorporation into MK-8 was observed $(I=3.3$ per cent $)$ and a very low dilution value $(D=1.4)$. Under comparable conditions $\left[1,4-{ }^{14} \mathrm{C}_{2}\right] 1,4$-naphthoquinone was less efficiently incorporated $(I=0.3$ per cent and $D=14.5)$. The possibility that the incorporation of the naphthoate represents an aberrant pathway through naphthoquinone itself cannot be ruled out. When the MK-8 labelled by $\left[2,3-{ }^{14} \mathrm{C}_{2}\right] 1,4-$ dihydroxy-2-naphthoate was degraded, the phthalate was without activity 


\section{BIOSYNTHESIS OF VITAMIN $\mathrm{K}$}

and the malonate contained approximately 50 per cent of the activity of the naphthylacetic acid. Hence, the conversion did proceed directly, a fact in keeping with the high $I$ and low $D$ values.

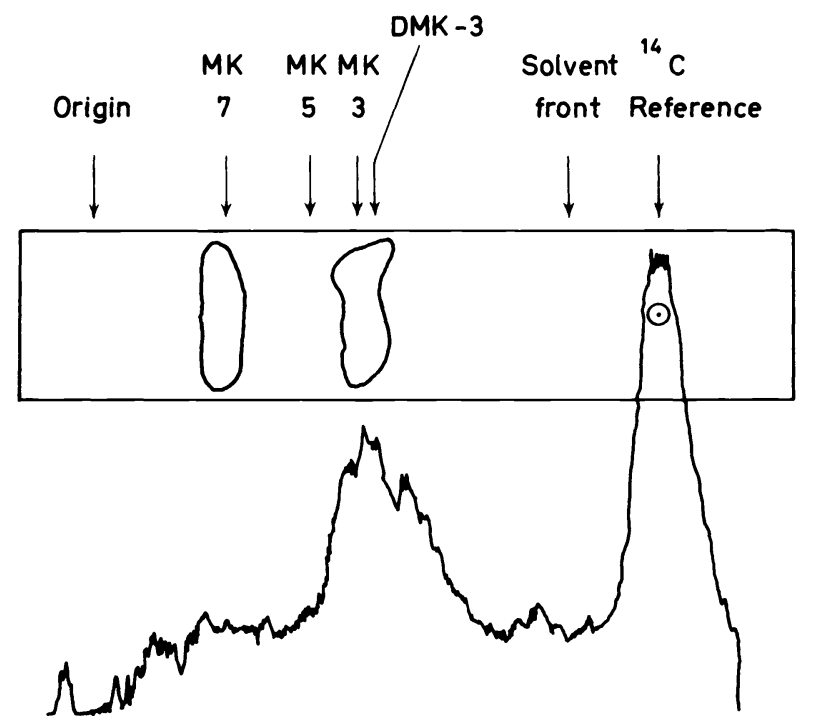

Figure 1. Cell-free synthesis of menaquinone. E. coli cell paste was disrupted in a French press in presence of EDTA. After incubation with $\left[2,3-{ }^{14} \mathrm{C}_{2}\right]$ dihydroxynaphthoic acid, farnesyl pyrophosphate and $\mathrm{MgCl}_{2}$, the menaquinone was isolated and purified. After addition of $100 \mu \mathrm{g}$ each of MK-3 and DMK-3, a reversed phase thin layer chromatography was carried out (silica gel plates were impregnated with paraffin oil and the solvent was acetone:water, 9:1). The known migration of reference MK samples is shown by the arrows. The chromatogram was scanned for ${ }^{14} \mathrm{C}$ in a Packard Chromatogram scanner, yielding the trace shown

In another attempt to document an intermediary role for the naphthoate, it has been incubated with a cell-free extract prepared from E. coli. In the presence of farnesyl pyrophosphate as an alkylating agent, evidence for the production of MK-3 (and/or DMK-3) was obtained (see Figure 1). Again it is not clear whether the naphthoate is an obligatory intermediate.<smiles>O=C(O)c1cc(O)c2ccccc2c1O</smiles><smiles>C1CCCCC1</smiles><smiles>[R]C1=C(C)C(=O)c2ccccc2C1=O</smiles><smiles>CC(=O)Oc1c(C)c(CC(=O)O)c(OC(C)=O)c2ccccc12</smiles><smiles>O=C(O)CC(=O)O</smiles> 


\section{RONALD BENTLEY}

\section{B. Naphthoquinones derived from o-succinylbenzoate-specific detail}

(i) The seven carbon pre-aromatic precursor Most of the experimental work on the biosynthesis of succinylbenzoate-derived naphthoquinones has used shikimate itself as the pre-aromatic precursor. However, the exact position at which naphthoquinone biosynthesis branches from the pathways to the essential amino acids is not determined. Some evidence tends to implicate chorismate, and plausible mechanisms can be written for either shikimate, chorismate or prephenate. Chorismate was considered by Dansette and Azerad as a result of the following observations ${ }^{19}$. The E. coli mutants 83-1 and 156-53 are blocked in early reactions of aromatic biosynthesis and do not form menaquinone; when an aromatic supplement and $10^{-4} \mathrm{M}$ succinylbenzoate were added, they formed the same amount of menaquinone as when fed with $0.2 \times 10^{-4} \mathrm{M}$ shikimate. However, with E. coli 159-4, which is blocked between shikimate and shikimate 3-phosphate*, supplementation with succinylbenzoate but not shikimate led to formation of menaquinone. It is at this time not clear whether chorismate is a mandatory precursor to succinylbenzoate in all cases. In one tracer experiment on juglone biosynthesis, Leistner and Zenk administered $\left[\mathrm{U}-{ }^{14} \mathrm{C}\right]$ chorismate to J. regia. Although excellent conversion to phenylalanine and tyrosine occurred ( $I=10.9$ and 4.9 per cent, respectively) with low dilutions, conversion to juglone was very poor $(I=0.028$ per cent $)$ and with very high dilution ${ }^{22}$. Threlfall has noted that this result is ambiguous in view of the known instability of chorismate under physiological conditions ${ }^{23}$; since it decomposes to 4-hydroxybenzoate and prephenate, the incorporation into the aromatic amino acids would still be possible. Dansette has reported conversion of $\left[5-{ }^{3} \mathrm{H}\right]$ chorismate to lawsone in $I$. balsamina with $I$ values of up to 0.5 per cent ${ }^{24}$.

(ii) Benzenoid aromatic precursors other than succinylbenzoate As already noted, Cox and Gibson claimed that the presence of 3,4-dihydroxybenzaldehyde prevented incorporation of activity from labelled shikimate to menaquinone in $E$. coli; hence, they assigned an intermediary role to 3,4-dihydroxybenzaldehyde ${ }^{3}$. Although Leistner et al. ${ }^{11}$ noted a similar result (in the presence of $10^{-4} \mathrm{M}$ 3,4-dihydroxybenzaldehyde the incorporation of activity from $\left[1,2-{ }^{14} \mathrm{C}_{2}\right]$ shikimate into menaquinone was suppressed by 40 per cent), Kelsey did not ${ }^{13}$. Further, labelled samples of 3,4-dihydroxybenzaldehyde and the corresponding acid are not converted to menaquinones by various bacteria ${ }^{9,11,25}$. One further point of contention in this area is the claim by Cox and Gibson ${ }^{4}$ that 3,4-dihydroxybenzaldehyde results in menaquinone formation by $A$. aerogenes $170-44$. This mutant cannot convert 5-enoylpyruvoyl shikimate-3-phosphate to chorismate, and requires addition of tryptophan, phenylalanine, tyrosine and 4-aminobenzoate to a basal medium. Guérin, Leduc and Azerad could not repeat this observation $^{25}$.

(iii) Location of the shikimate carboxyl in menaquinone In 1970 Leduc, Dansette and Azerad established that the ring junction of the naphthalene

\footnotetext{
* 'Chemical' numbering of shikimate is used throughout this paper.
} 
BIOSYNTHESIS OF VITAMIN K
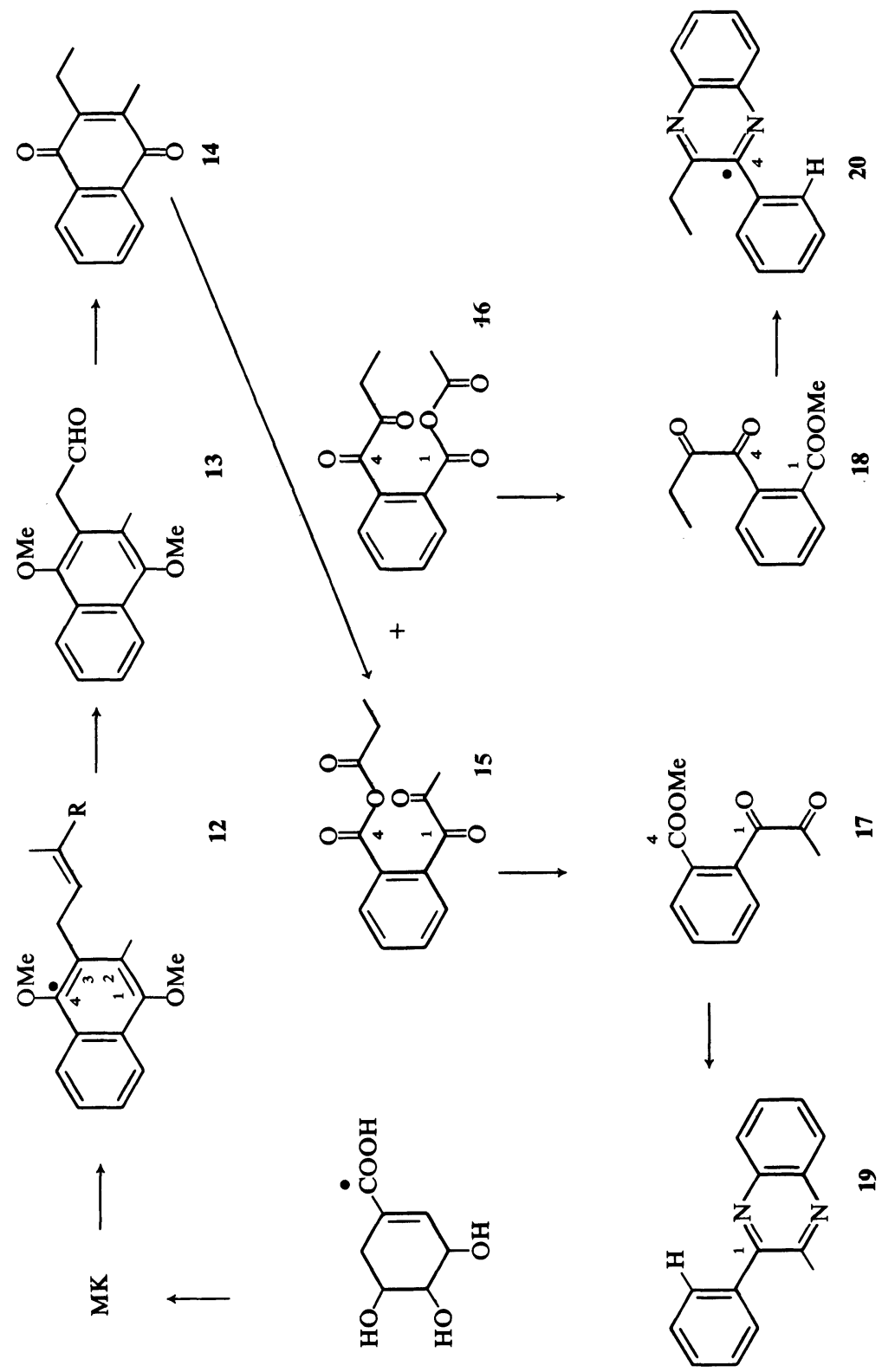


\section{RONALD BENTLEY}

system (i.e. C-9 and C-10) originates from the ethylenic carbon atoms of shikimate (i.e. C-1 and C-2) ${ }^{26}$. More recently, Baldwin, Snyder and Rapoport have devised an elegant degradation of menaquinone so that an independent determination of radioactivity at each quinone position can be made ${ }^{27}$. The menaquinone obtained by feeding $\left[7-{ }^{14} \mathrm{C}\right]$ shikimate to $M$. phlei was converted by way of (12) and (13) to 2-methyl-3-ethyl-naphthoquinone (14), which in turn was degraded by ozonolysis. The mixed ozonides $(15+16)$ were converted to the esters $(\mathbf{1 7}+\mathbf{1 8})$, and this mixture was separated by gas chromatography. After converting the $\alpha$-diketones to quinoxaline derivatives, the separate esters were hydrolysed and the resulting acids were decarboxylated. In this way were obtained the derivatives (19) containing only C-1 and (20) containing only C-4. Since only the latter contained ${ }^{14} \mathrm{C}$, $\left[7-{ }^{14} \mathrm{C}\right]$ shikimate labels $\mathrm{C}-4$ exclusively.<smiles>[R]C1=C([Tl])C(=O)c2ccccc2C1=O</smiles>

Using another degradation, Dansette has shown that the aromatic carboxyl group of succinylbenzoate also labels C-4 of menaquinone ${ }^{24}$. In this work the menaquinone was converted via phthiocol (21) to lawsone (9). The lawsone was then converted to the acid (22) by reaction with $\mathrm{HN}_{3}$; in turn, the acid was hydrolysed and decarboxylated to the acetophenone carboxylic acid (23). Finally (23) was converted to phthalate and iodoform in one operation and in a second to acetyl anthranilate (24) - the latter was hydrolysed quantitatively to acetate and anthranilate. From succinylbenzoate labelled in the aromatic carboxyl group, label was found only in acetate. 


\section{BIOSYNTHESIS OF VITAMIN $\mathrm{K}$}

The results obtained by Rapoport's group and by Dansette are in perfect agreement. Furthermore, they also prove that there are no symmetrical intermediates involved in the pathway to menaquinone*. This work reinforces an earlier observation on the fate of the prochiral hydrogen atoms at C-6 of shikimate during MK biosynthesis ${ }^{28}$. In $B$. megaterium $(6 R)-\left[7-{ }^{14} \mathrm{C}\right.$, $\left.6-{ }^{3} \mathrm{H}\right]$ shikimate gave MK-7 containing ${ }^{14} \mathrm{C}$ but no ${ }^{3} \mathrm{H}$; the use of the $[6 \mathrm{~S}]$ material showed retention of ${ }^{3} \mathrm{H}$. However, in juglone biosynthesis all of the $[6 R]$ proton was lost and only about one-half of the ${ }^{3} \mathrm{H}$ from the pro-6S position was retained. At least one symmetrical intermediate was, therefore, postulated on the pathway to juglone. In fact, labelled naphthoquinone is known to be converted to juglone ${ }^{29}$.

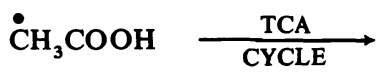<smiles>O=C(O)CCC(=O)C(=O)O</smiles><smiles>O=C1C=C(O)C(=O)c2ccccc21</smiles><smiles>Cc1cc(=O)c(=O)c1=O</smiles><smiles>CCC</smiles><smiles>CC(=O)c1ccccc1C(=O)C(=O)O</smiles><smiles>CCC</smiles><smiles>CC(=O)C(=O)c1ccccc1C(=O)O</smiles><smiles>C=C</smiles>

26

Moreover, of the succinylbenzoate-derived naphthoquinones, juglone appears to be the exception. Grotzinger and Campbell found that the other simple plant naphthoquinone, lawsone, did not use a symmetrical intermediate ${ }^{30}$. In their work $\left[2-{ }^{14} \mathrm{C}\right]$ acetate was used to provide a source of $\left[4-{ }^{14} \mathrm{C}\right] 2$-ketoglutarate. The labelled lawsone was treated with base and iodine. The ring opens to yield the two acids (25) and (26), and from each one $\mathrm{C}-3$ is obtained as iodoform. It was found that only 16 per cent of total activity from $\left[2-{ }^{14} \mathrm{C}\right]$ acetate was present in $\mathrm{C}-3$, most of it being in C-2. The label in C-3 most likely results from scrambling in the citric acid cycle. Thus, these results provide no evidence for a symmetrical biosynthetic intermediate between succinylbenzoate and lawsone. (In control experiments with $\left[3,4-{ }^{14} \mathrm{C}_{2}\right]$ glutamate, the activity was equally distributed between $\mathrm{C}-2$ and C-3 of lawsone - as predicted.)

* Symmetrical intermediates could exist if they contained prochiral centres. 


\section{RONALD BENTLEY}

(iv) A role for 1-naphthol? In 1967 Leistner et al. observed an incorporation of activity from $\left[1-{ }^{14} \mathrm{C}\right] 1$-naphthol into MK-7 of $B$. megaterium ( $I=1.5$ per cent); degradation showed the activity to be localized in C-1 and/or C- $4^{11}$. The activity of the MK-7 was retained after rigorous purification. Since then, similar incorporation into menaquinones has been noted in Staphylococcus aureus and A. aerogenes ${ }^{25,31,32}$. In our work $\left[1-{ }^{14} \mathrm{C}\right] 1-$ naphthol was a very poor precursor to menaquinones in E. coli and $M$. phlei, and the organisms in which it does not function as a precursor considerably outnumber those in which it does. Most workers now agree that it is not an obligatory intermediate.

Indirect evidence confirming this conclusion has come from a study of the origin of the oxygen atoms in the menaquinone molecule. With the aid of careful control experiments, Snyder and Rapoport have shown that the quinone oxygen functions arise biosynthetically from water, and not from oxygen of the atmosphere ${ }^{33}$. If 1-naphthol is an intermediate, the introduction of the second oxygen atom would be by way of an aromatic hydroxylation: all such hydroxylations so far studied utilize molecular oxygen. Hence, the failure to incorporate ${ }^{18} \mathrm{O}$ into the $\mathrm{MK}-9\left(\mathrm{II}-\mathrm{H}_{2}\right)$ of $M$. phlei from ${ }^{18} \mathrm{O}_{2}$ argues against a role for 1-naphthol.

\section{Naphthoquinones derived from 4-hydroxybenzoate}

So far, there is experimental evidence to implicate 4-hydroxybenzoate as a precursor to only one naphthoquinone-namely the plant product, alkannin (28). It appears likely, however, to be involved in some other cases as well. In tracer studies with alkannin formed on the leaf surface of Plagiobothrys arizonicus, Schmid and Zenk found no incorporation of activity from $\left[7-{ }^{14} \mathrm{C}\right]$ shikimate and $\left[\mathrm{U}-{ }^{14} \mathrm{C}\right]$ tyrosine ${ }^{34}$. However DL- $\left[\right.$ ring-1- $\left.{ }^{14} \mathrm{C}\right]$ phenylalanine and [ring-1-14 $\mathrm{C}$ ]cinnamate (27) did label the pigment with $I$ values

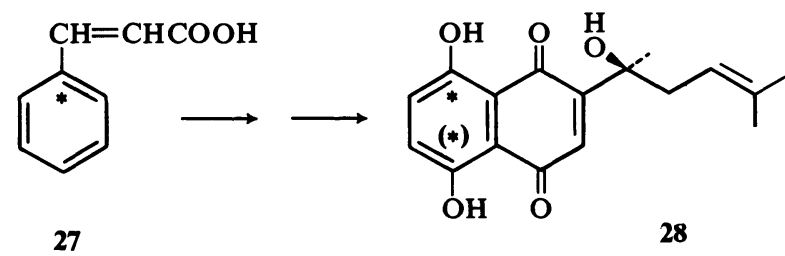

of 0.66 and 0.48 per cent, respectively. Degradation experiments established that the activity from cinnamate was present at C-5 and/or C-8 of alkannin. Furthermore, $\left[1,2,6-{ }^{14} \mathrm{C}_{3}\right]$-hydroxybenzoate was a good precursor $(I=$ 1.36 per cent) and the rest of the molecule was found to originate in mevalonate. With DL- $\left[2-{ }^{14} \mathrm{C}\right]$ mevalonate $(I=0.51$ per cent $), 51$ per cent of total activity was located in the terminal methyl groups of the side chain. Hence, a pathway involving prenylation of 4-hydroxybenzoate (29) either successively with two molecules of isopentenyl pyrophosphate or with geranyl pyrophosphate (30) (or hydroxylated derivative thereof) was postulated. This pathway is, in general, similar to that of ubiquinone biosynthesis. 
<smiles>CC(C)=CCCC(C)=CCO[PH2+]</smiles>

29<smiles>CC(C)=CCCC(C)=CCc1cc(C(=O)O)ccc1O</smiles><smiles>[13CH2][13CH3]</smiles><smiles>CC(C)=CC[C@](C)(O)C1=CC(=O)c2c(O)ccc(O)c2C1=O</smiles>

A series of terpenoid quinones-the cordiachromes (34-36)-has been isolated from heartwood of Cordia millenii, Patagonula americana, etc. ${ }^{35}$. Moir and Thomson believe that these quinones are also derived from the alkannin precursor (31), and support for this idea is found in the co-occurrence of alkannin and cordiachromes in the genus Boraginaceae. Further support is the isolation of a likely intermediate-alliodorin (32)- from Cordia alliodora ${ }^{36}$.<smiles>C=C[C@H]1CC2=C(C(=O)C=CC2=O)[C@H](OC)[C@@H]1C(=C)CC</smiles>

\section{Naphthoquinones derived from homogentisate}

Although homogentisate (37) has an important function as a precursor to quinones such as plastoquinone, and to the tocopherols, it is recognized as a precursor to only a single naphthoquinone-chimaphilin $(39)^{37}$. As is true for alkannin biosynthesis, the second ring is constructed from four 


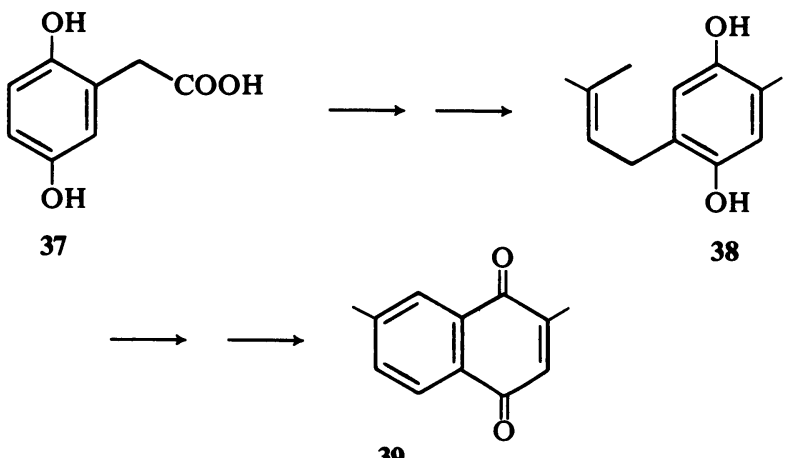

carbon atoms derived from mevalonate; presumably an intermediate such as (38) is required. It should be noted that some anthraquinones are derived similarly by addition of mevalonate to a naphthoquinone.

\section{NAPHTHOQUINONES DERIVED FROM ACETATE}

The finding that naturally occurring binaphthoquinones could be derived by a polyketide pathway was reported by Allport and Bu'Lock in $1960^{38}$. Since that time, a number of simple naphthoquinones (in fungi and plants) have been shown to originate from acetate and polymalonate pathways. Of considerable interest is a re-examination of mollisin (40) biosynthesis. By the use of acetate labelled in both positions with ${ }^{13} \mathrm{C}$, Seto, Cary and Tanabe have elucidated the nature of the two chains known to be involved ${ }^{39}$. These are a triketide and a pentaketide condensing as shown below; the further implication is that a terminal methyl group undergoes chlorination.<smiles>CC(=O)CC(=O)CC(=O)CC(=O)CC(=O)CC(=O)CC(C)(C)C(=O)O</smiles><smiles>CC1=CC(=O)c2c(O)cc(C)c(C(=O)C(Cl)Cl)c2C1=O</smiles>

40

A number of natural naphthoquinones contain neither $\mathrm{CH}_{3}$ nor $\mathrm{COOH}$ groups, which are generally diagnostic for the acetate polymalonate route. Among these, flaviolin-2,5,7-trihydroxynaphthoquinone (41)-has an interesting history. The original structure assignment was based on a biosynthetic origin from acetate, and this compound has frequently been cited as derived from a polyketide. With the discovery that compounds such as 
BIOSYNTHESIS OF VITAMIN $\mathrm{K}$

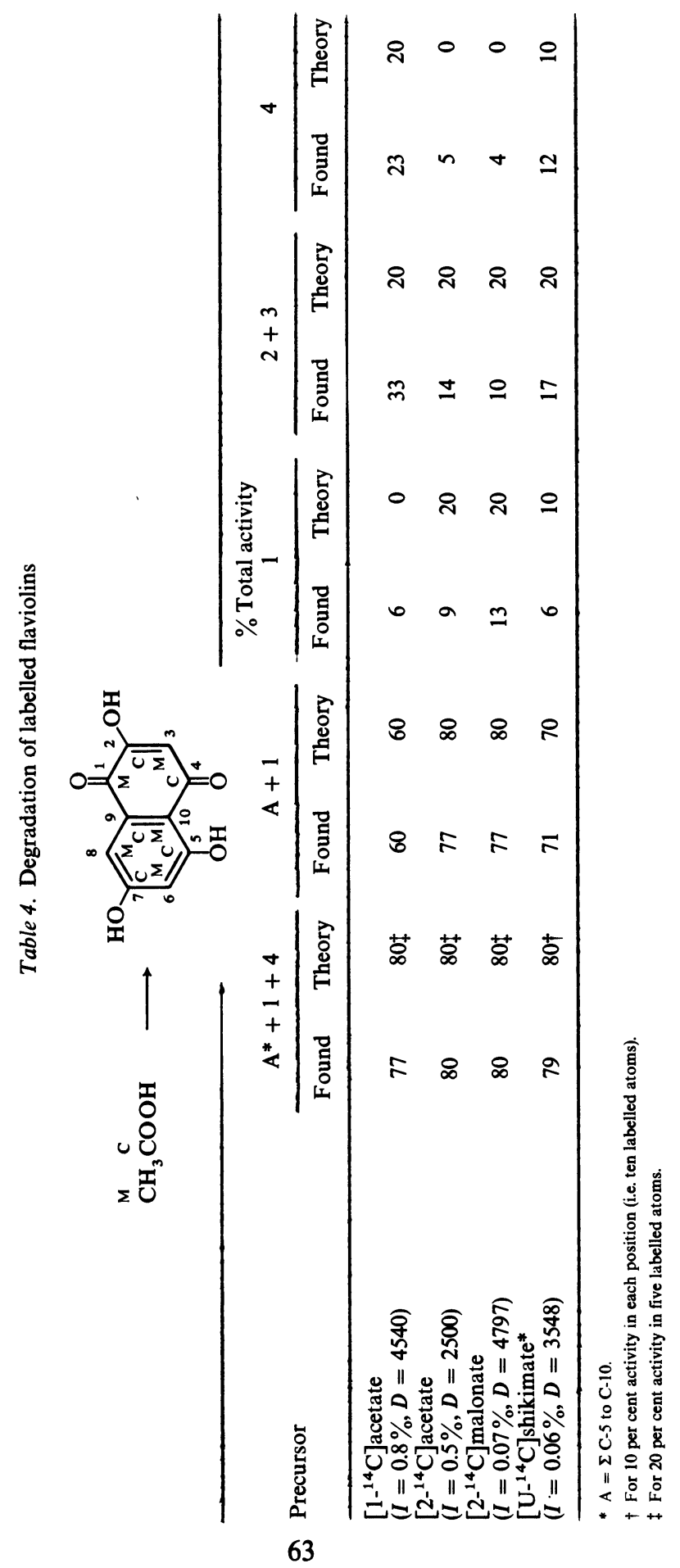




\section{RONALD BENTLEY}

juglone and lawsone were not acetate-derived, an experimental verification of flaviolin biosynthesis was necessary.

Although acetate and malonate were well incorporated into flaviolin by Aspergillus niger ( $I$ values from 0.07 to 2.5 per cent), it was disconcerting to find, as well, significant incorporations of activity from $\left[\mathrm{U}-{ }^{14} \mathrm{C}\right]$ shikimate ( $I$ values from 0.06 to 0.56 per cent). For chemical degradation, the tri- $O$ methyl derivative (42) was oxidized to 3,5-dimethoxyphthalate (43), which in turn was converted to 3,5-dihydroxybenzoate (44). The distribution patterns obtained with the labelled acetates and malonates are shown in Table 4; they are completely consistent with the 'alternating pattern' shown below. From $\left[\mathrm{U}-{ }^{14} \mathrm{C}\right]$ shikimate, however, the degradations indicated a uniform labelling at all carbon positions. Hence, it appears that the shikimate incorporations result from its degradation to uniformly labelled acetate.

Evidence has also been obtained showing that the 2,7-dimethoxy naphthazarin (46) produced by Streptomycete 12396 is a polyketide product. In this work the organism was grown as a shake culture on moist rice grains ('solid state fermentation' ${ }^{40}$ ). In a few hours the rice grains became pink and after $48 \mathrm{~h}$, acquired the colour of 'new blue jeans'. The yield of naphthazarin from $250 \mathrm{~g}$ of rice in a 2.8 litre Fernbach flask was typically $150-200 \mathrm{mg}$ after 5 days. By adding ${ }^{14} \mathrm{C}$-labelled tracers in a few drops of water, excellent incorporation values were obtained (from 2.5 to 18.5 per cent for labelled acetate and malonate). Incorporations of $\left[\mathrm{U}^{14} \mathrm{C}\right]$ shikimate, $\left[\mathrm{U}-{ }^{14} \mathrm{C}\right] \mathrm{L}$-glutamate and $\left[2,3-{ }^{14} \mathrm{C}\right] \mathrm{o}$-succinylbenzoate were much lowerrespectively, $0.86,0.16$ and 0.0016 per cent.<smiles>COC1=CC(=O)c2c(OC)cc(OCC(C)(C)C)cc2C1=O</smiles>

41

42<smiles>COc1cc(OC)c(C(=O)O)c(C(=O)O)c1</smiles><smiles>COc1cc(OC)c2c(c1)C(=O)OC2=O</smiles><smiles>C[14CH2]</smiles><smiles>O=C(O)c1cc(O)cc(O)c1</smiles><smiles>C[Te]C(=O)O</smiles> 


\section{BIOSYNTHESIS OF VITAMIN $\mathrm{K}$}

On treatment of the naphthazarin samples with alkaline iodine, C-3 (=C-6) was released as iodoform. As shown in Table 5, the percentage total activity in the iodoform was consistent with an acetate polymalonate origin. The iodoform obtained from naphthazarin biosynthesized from $\left[\mathrm{U}-{ }^{14} \mathrm{C}\right]-$ shikimate contained ten per cent of total activity-suggesting breakdown to $\left[1,2-{ }^{14} \mathrm{C}_{2}\right]$ acetate as in the case of flaviolin.

Table 5. Biosynthesis of 2,7-dimethoxynaphthazarin by Streptomycete 12396
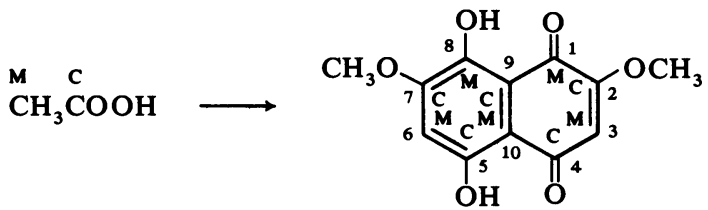

\section{Precursor}

$\%$ Total activity in C-3 (=C-6)

Found

Theory

$\left[1-{ }^{14} \mathrm{C}\right]$ acetate

$(I=2.5 \%, D=11190)$

0.8

0

$\left[2-{ }^{14} \mathrm{C}\right]$ acetate

$(I=3.7 \%, D=5895)$

16.0

$\left[2-{ }^{14} \mathrm{C}\right]$ malonate

$(I=18.5 \%, D=362)$

19.0

Furthermore, flaviolin (prepared by growth of $A$. niger on $\left[2-{ }^{14} \mathrm{C}\right]-$ malonate) and mompain (45, prepared by demethylation of 2,7-dimethoxynaphthazarin) were very effective precursors; $I=10.3$ per cent, $D=17.1$ for flaviolin, and $I=39.1$ per cent, $D=11.4$ for mompain. Hence, the pathway to the dimethoxynaphthazarin appears to be as follows.

$$
\stackrel{\bullet}{\mathrm{CH}_{3}} \stackrel{\bullet}{\mathrm{COOH}}
$$<smiles>O=C1C(O)=CC(=O)c2c(O)cc(O)cc21</smiles><smiles>O=C1C=C(O)C(=O)c2c(O)c(O)cc(O)c21</smiles><smiles>COC1=CC(=O)c2c(O)c(OC)cc(O)c2C1=O</smiles>

45 


\section{NAPHTHOQUINONES DERIVED FROM MEVALONATE}

Some $o$-quinones (e.g. the mansonones (47), biflorin (48)) have a carbon skeleton which obeys the Empirical Isoprene Rule. These are clearly terpenoid components derived from mevalonate. Little direct experimental

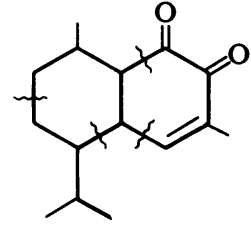

47

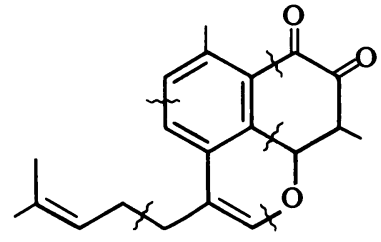

48

verification is available. However, the related (albeit non-quinonoid) compound, gossypol (50), formed in the cotton plant, is known to be labelled in the anticipated manner by mevalonate. In a cell-free enzyme system, cis-cis farnesyl pyrophosphate was the most effective precursor of the possible isomers tested. Folding occurs as shown below ${ }^{41}$.

6 Mevalonate<smiles>CCCOCC=C(C)CCCC(C)=CCCC(C)C</smiles><smiles>Cc1cc2c(C(C)C)c(O)c(O)c(C=O)c2c(O)c1-c1c(C)cc2c(C(C)C)c(O)c(O)c(C=O)c2c1O</smiles>

$\Delta=$ Label from

$\left[2-{ }^{14} \mathrm{C}\right]$ farnesyl

pyrophosphate

50

\section{UNIDENTIFIED PATHWAYS}

Ansamycins such as rifamycin, streptovaricin, tolypomycin and halomicin contain a naphthalene nucleus spanned by a long aliphatic bridge. Recent publications leave no doubt that for the rifamycins and streptovaricins the ansa chain is derived mainly from propionate (presumably methylmalonate) units $^{42-44}$. The origin of the naphthalene system is still in doubt, but a 


\section{BIOSYNTHESIS OF VITAMIN $\mathrm{K}$}

seven-carbon unit apparently initiates a polyketide chain. Of the three other necessary atoms, two derive from a propionate unit, one from an acetate unit. The seven-carbon fragment is clearly not of polyketide origin; and although a shikimate unit seems a likely possibility, no incorporation of activity from labelled shikimate into rifamycin was observed with Nocardia mediterrane $i^{43}$. Evidence has recently been obtained to implicate one of the intermediates between 3-deoxy-D-arabino-heptulosonic acid 7-phosphate and shikimate ${ }^{45}$. Whatever the nature of the seven-carbon fragment, it is clear that this represents a further pathway for elaboration of a naphthoquinone system.

It is believed that a common precursor to the naphthalene ansamycins is $\mathbf{5 1}$, formed by the condensation:

C-7 unit $\rightarrow$ propionate $\rightarrow$ acetate $\rightarrow$ (propionate) $)_{6} \rightarrow$ acetate $\rightarrow$ propionate

Rearrangement leads, for example, to rifamycin S (52).
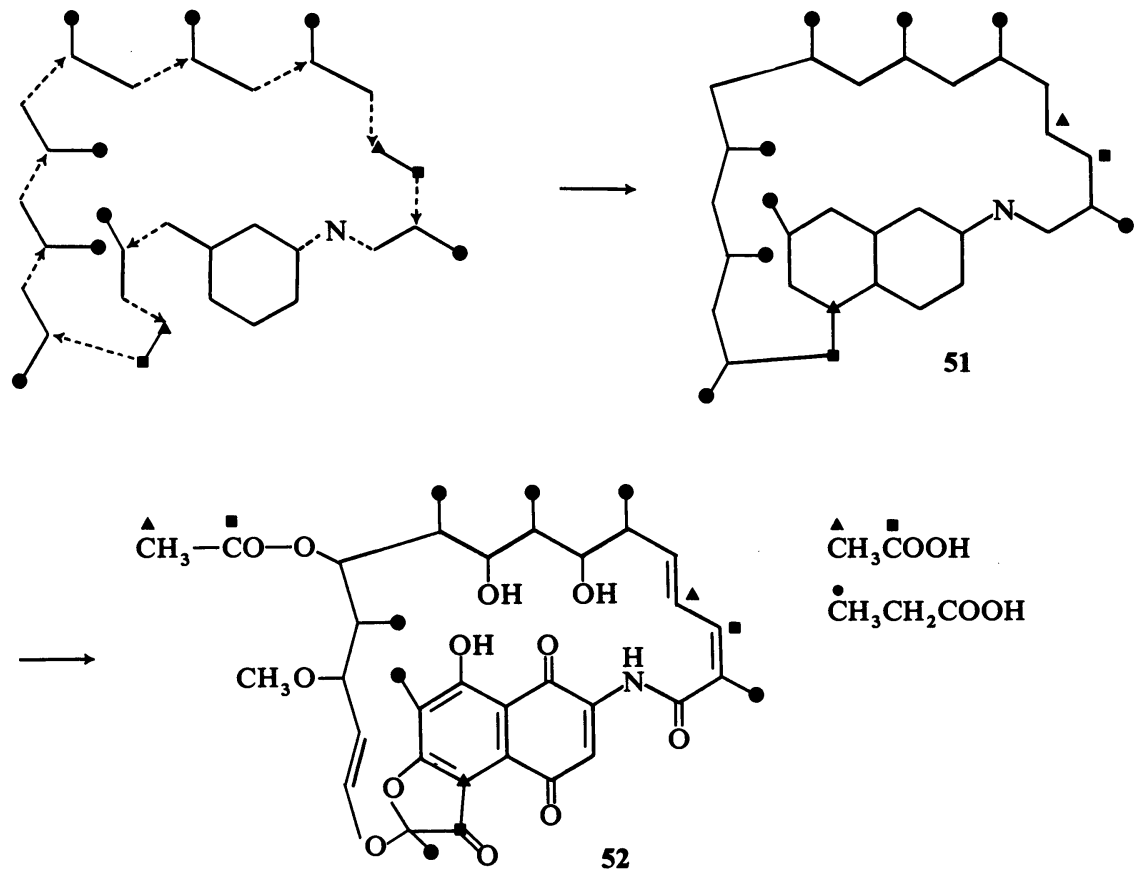

\section{ACKNOWLEDGEMENTS}

Previously unreported data described here were obtained by $\mathrm{Dr} \mathrm{R}$. Bryant and Mr E. McGovern. The work was supported, in part, by a grant from the US Public Health Service, GM-20053, and from the National Science Foundation, GB-37503. 


\section{RONALD BENTLEY}

\section{REFERENCES}

${ }^{1}$ R. H. Thomson, Naturally Occurring Quinones, 2nd edn. Academic Press: New York (1971).

2 For a recent review see R. Bentley, in Biosynthesis (Specialist Periodical Report--The Chemical Society), 3, 181 (1975).

3 G. B. Cox and F. Gibson, Biochim. Biophys. Acta, 93, 204 (1964).

4 G. B. Cox and F. Gibson, Biochem. J. 100, 1 (1966).

5 G. R. Whistance, D. R. Threlfall and T. W. Goodwin, Biochem. Biophys. Res. Commun. 23, 849 (1966).

${ }^{6}$ E. Nyström and J. Sjövall, J. Chromatogr. 24, 212 (1966).

${ }^{7}$ I. M. Campbell and R. Bentley, Biochemistry, 7, 3323 (1968).

8 I. M. Campbell and R. Bentley, Biochemistry, 8, 4651 (1969).

9 I. M. Campbell, C. J. Coscia, M. Kelsey and R. Bentley, Biochem. Biophys. Res. Commun. 28, 25 (1967).

10 I. M. Campbell, D. J. Robins, M. Kelsey and R. Bentley, Biochemistry, 10, 3069 (1971).

11 E. Leistner, J. H. Schmitt and M. H. Zenk, Biochem. Biophys. Res. Commun. 28, 845 (1967).

12 For review see R. Bentley and I. M. Campbell in The Chemistry of the Quinonoid Compounds (ed. S. Patai), p. 683. Wiley: Chichester (1974).

13 M. Kelsey, PhD Thesis, University of Pittsburgh (1969).

${ }^{14}$ M. H. Zenk and E. Leistner, Z. Naturforsch. 22b, 460 (1967).

15 I. M. Campbell, Tetrahedron Letters, 4777 (1969).

16 D. J. Robins, I. M. Campbell and R. Bentley, Biochem. Biophys. Res. Commun. 39, 1081 (1970).

17 D. J. Robins and R. Bentley, J. Chem. Soc. Chem. Commun. 232 (1972).

18 E. Grotzinger and I. M. Campbell, Tetrahedron Letters, 4685 (1972).

19 P. Dansette and R. Azerad, Biochem. Biophys. Res. Commun. 40, 1090 (1970).

20 I. M. Campbell, E. W. Grotzinger, J. Naworal and C. P. Nulton, Abstracts, Ninth International Symposium on the Chemistry of Natural Products (IUPAC), 27C (1974).

21 D. J. Robins, R. B. Yee and R. Bentley, J. Bacteriol. 116, 965 (1973).

22 E. Leistner and M. H. Zenk, Z. Naturforsch. 23b, 259 (1968).

23 D. R. Threlfall in Vitamins and Hormones (eds. R. S. Harris, E. Diczfalusy, P. L. Munson and J. Glover), 29, 153 (1971).

24 P. Dansette, Docteur ès-Sciences Thesis, Université de Paris-Sud, Centre d'Orsay (1972).

25 M. Guérin, M. M. Leduc and R. G. Azerad, Europ. J. Biochem. 15, 421 (1970).

26 M. M. Leduc, P. M. Dansette and R. G. Azerad, Europ. J. Biochem. 15, 428 (1970).

27 R. M. Baldwin, C. D. Snyder and H. Rapoport, J. Amer. Chem. Soc. 95, 276 (1973); Biochemistry, 13, 1523 (1974).

${ }^{28}$ K.-H. Scharf, M. H. Zenk, D. K. Onderka, M. Carroll and H. G. Floss, Chem. Commun. 576 (1971).

29 E. Leistner and M. H. Zenk, Z. Naturforsch. 23b, 259 (1968).

30 E. Grotzinger and I. M. Campbell, Phytochemistry, 11, 675 (1972).

31 R. K. Hammond and D. C. White, J. Bacteriol. 100, 573 (1969).

32 Results of D. M. Hurd, cited in reference 23.

33 C. D. Snyder and H. Rapoport, Biochemistry, 9, 2033 (1970).

${ }^{34}$ H. V. Schmid and M. H. Zenk, Tetrahedron Letters, 4151 (1971).

35 M. Moir and R. H. Thomson, J. Chem. Soc. Perkin I, 1352, 1556 (1973).

${ }^{36}$ K. L. Stevens, L. Jurd and G. Manners, Tetrahedron Letters, 2955 (1973).

${ }^{37}$ K. H. Bolkart and M. H. Zenk, Z. Pflanzenphysiol. 61, 356 (1969).

38 D. C. Allport and J. D. Bu'Lock, J. Chem. Soc. 654 (1960).

39 H. Seto, L. W. Cary and M. Tanabe, J. Chem. Soc. Chem. Commun. 867 (1973).

40 C. W. Hesseltine, Biotechnology and Bioengineering, 14, 517 (1972).

41 P. G. Heinstein, D. L. Herman, S. B. Tove and F. H. Smith, J. Biol. Chem. 245, 4658 (1970).

42 M. Brufani, D. Kluepfel, G. C. Lancini, J. Leitich, A. S. Mesentsev, V. Prelog, F. P. Schmook and P. Sensi, Helv. Chim. Acta, 56, 2315 (1973).

43 R. J. White, E. Martinelli, G. G. Gallo, G. Lancini and P. Beynon, Nature, 243, 273 (1973).

44 B. Milavetz, K. Kakinuma, K. L. Rinehart, J. P. Rolls and W. J. Haak, J. Amer. Chem. Soc. 95, 5793 (1973).

45 R. J. White, personal communication. 